\title{
Legal Protection of Children in the Investigation Process by Investigators Based on Restorative Justice
}

\author{
Askohar $^{*}$ and Siti Rodhiyah Dwi Istinah ${ }^{* *}$ \\ ${ }^{*}$ Grobogan Resort Police email asko.figo@gmail.com \\ **) Faculty of Law Universitas Islam Sultan Agung
}

\begin{abstract}
This study aims to analyze more deeply related to child protection in the current investigation process. The type of approach in this research is sociological juridical. Based on the analysis of the existing data, it was found that the child protection in the investigation process in Central Java has not been able to run effectively, Most of the children or adolescents in Central Java who are in conflict with the law are decided by the judge to enter the juvenile prison. In addition, the lengthy legal process against children in conflict with the law results in the child being depressed and can make the child's psychology more shaken. This will obviously result in the growth and development of the child's soul and also the future of the child. Restorative justice is present as another effort to enforce the law by not injuring children's rights, restorative justice is carried out by diversion. Restorative justice in handling children in conflict with the law can be pursued in law enforcement through diversion efforts. Implementation of diversion in the case of children for children with a criminal sanction of 1 year.

Keywords: Children; Protection; Investigation; Restorative Justice.
\end{abstract}

\section{Introduction}

Assurance of protection of dignity, children are entitled to special protection, especially legal protection in the judicial system as a consequence of Indonesia as a state party to the Convention on the Rights of the Child (Convention on the Rights of the Child) which regulates the principle of legal protection of children has an obligation to provide special protection against children in conflict with the law.

Diversion in Article 1 number 7 of Act No. 11 of 2012 concerning the Juvenile Justice System is the process of resolving cases of children in conflict with the law, from the criminal justice process to processes outside of criminal justice, with deliberation involving children, parents of children, community advisors, to prevent children from deprivation of liberty is intended to keep children away from the criminal justice process. The criminal justice system in Indonesia is considered not to be in favor of child offenders or children who are in conflict with the law, the existing criminal law products are considered rooted in the existing social structure of society, 
in this case the criminal law products on children only regulate victims of criminal crimes. ${ }^{1}$

The reason for being imprisoned is that judges often use judicial and discretionary policies, rather than sociological considerations, not only that many judges ignore community research, even though not a few community structures in Indonesia experience social pathology and judges ignore community research from BAPAS. ${ }^{2}$ Minors still have a volatile nature and are easily uncontrolled by circumstances from within themselves and the surrounding environment, in the case of facts in society, children who are in conflict with the law still lack the ability to control themselves over the influence of the social environment outside the home which is negative, the lack of supervision of both parents so that they are influenced by friends in the surrounding environment, in carrying out actions they are still relatively unstable. ${ }^{3}$

Distrust of prisons or fostering children is not effective, the authors conclude that children in conflict with the law need to be done with diversion at all levels so that children who still have a long future and still need guidance from both parents, if diversion is not carried out, many children who go to prison or foster care and children's rights guaranteed by the law on child protection are not fulfilled, so that it will cause children to be physically disturbed and make children stupid and easily colonized by others and will have a major impact on growth a child as an adult may become a child when an adult becomes a recidivist offender.

Child protection in its development not only includes the protection of their rights but also relates to aspects of the development of the younger generation, taking into account that children are not individualists because children are still very dependent on adults, especially adults they know, in addition to the fact that that the child has not been able to support himself. This situation is clearly contrary to the purpose of the rule of law in the concept of development law. So that in its development the law should be able to realize justice for children so that they are able to support children's lives that are guaranteed, beneficial and have legal certainty. ${ }^{4}$ So the purpose of this paper is to find out and analyze related to child protection in the current restorative justice-oriented investigation process.

\footnotetext{
${ }^{1}$ Gatot Supramono, 2007, Hukum Acara Pengadilan Anak, Jakarta: Djambatan, p. 1.

2 Solopos.com, 2016, Friday 20 May 2016, at 05.00 WIB : $90 \%$ of children facing the law end up in prison, in http://www.solopos.com/2016/05/20/90-anak-berhadapanHukumberakhir- in-jail-721069

${ }^{3}$ M Ghufran H. Kordi K, 2015, Durhaka Kepada Anak Refleksi Mengenai Hak \& Perlindungan Anak, Yogyakarta: Pustaka Baru Press, p. 238.

${ }^{4}$ Nur Cahyanti, Budi Raharjo, and Sri Endah Wahyuningsih, "Sanksi Terhadap Notaris Yang Melakukan Tindak Pidana Menurut Peraturan Perundang-Undangan Di Indonesia”, Jurnal Akta, Vol 5 No 1 March 2018, p. 91.
} 


\section{Research Methods}

The type of research used in this study is a descriptive analytical legal research type. The type of approach in this writing is sociological juridical. Methods of data collection using literature study, field observations, and interviews. The data processing method is carried out qualitatively.

\section{Results and Discussion}

\subsection{Protection of Children in the Current Legal Process}

Discussion on legal protection for children is related to the provision of children's rights. Child protection is nothing but all activities to guarantee and provide protection for children and their rights so that they can live, grow and develop optimally, and participate optimally in accordance with human dignity and protection from violence and discrimination. Children have the right to welfare, care, upbringing, guidance based on affection, both in their families and in special care for normal growth and development. Protection of children's rights is largely determined by the existence of a child protection policy, child welfare policy. The Indonesian state has committed to making child protection the most basic thing, this is reflected in the regulations concerning which are explicitly regulated in the constitution. The Child Protection Law states that children in conflict with the law are entitled to humane treatment and placement separately from adults, to obtain legal aid or other assistance according to the stages of legal remedies in force and to defend themselves and obtain objective justice before an impartial court.

The provision of special protection for children in conflict with the law, especially those in conflict with the law, is an obligation and responsibility of the state as regulated in Article 64 of the Child Protection Law, carried out in the following forms:

- Protection of children humanely in accordance with the dignity and worth of the child

- Provision of special assistance officers for children from an early age

- Provision of special facilities and infrastructure

- Imposition of appropriate sanctions in the best interests of the child

- Continuous monitoring and disability on the development of children in conflict with the law

- Providing guarantees to maintain relationships with parents or family; and

- Protection from identity reporting through mass media and to avoid labeling

\subsection{Effectiveness of Child Protection in Restorative Justice Oriented Legal Processes}

Act No. 11 of 2012 concerning the Juvenile Criminal Justice System, all 
of which put forward general principles of child protection, namely nondiscrimination in the best interests of children, respect for survival and growth and development. The presence of these regulations has formulated the protection of children's rights, but in reality they have not yet received treatment that is very beneficial for the best interests of the child. ${ }^{5}$

Article 1 number 2 of the Republic of Indonesia Act No. 35 of 2014 concerning Child Protection is formulated that "Child Protection is all activities to guarantee children and their rights so that they can live, grow, develop and participate optimally in accordance with human dignity and protection from violence and discrimination". Children are a group that is vulnerable to the occurrence of a criminal act in conflict with the law, both as perpetrators of criminal acts, as well as victims of criminal acts as well as children who are witnesses to criminal acts, as formulated in Article 1 points 2, 3, 4 and 5 of the Act No. 11 of 2012 concerning the Juvenile Criminal Justice System.

Children have specific rights that are different from the rights of adults, this is because children are very vulnerable to violence, abuse and exploitation. ${ }^{6}$ Various criminal cases involving children having to deal with the law are actual and factual problems as social and criminal phenomena that have caused concern among parents in particular and society in general as well as law enforcers. ${ }^{7}$ The forms of crime and crimes that are mostly committed by children include theft, drug abuse, fights, crimes of sexual harassment, traffic violations, and persecution to murder cases and motorcycle gang crimes (Robber) whose perpetrators are children. ${ }^{8}$ Other facts also show that children in various cases have to face the law as victims of violent treatment, including physical, psychological, sexual abuse and neglect. ${ }^{9}$

The current Juvenile Criminal Justice System refers to Act No. 11 of 2012 , in the mechanism of the process, the process still has to go through a formal process like an adult by going through the process of investigation and investigation by the police, the prosecution process by the prosecutor's office and trial in court. This long formal process gave birth to several thoughts from both scientists and law enforcement officers to find the best

\footnotetext{
5 Yul Ernis, "Diversi Dan Keadilan Restoratif Dalam Penyelesaian Perkara Tindak Pidana Anak Di Indonesia", Jurnal Ilmiah Kebijakan Hukum, Vol.10, No.2, July 2016, 163-174.

${ }^{6}$ Nur Rochaeti, "Implementasi Keadilan Restoratif dan Pluralisme Hukum Dalam Sistem Peradilan Pidana Anak di Indonesia, Jurnal Masalah-Masalah Hukum, Vol. 44, No.2, April 2015, p.150

${ }^{7}$ Ulang Mangun Sosiawan, "Perspektif Restorative Justice Sebagai Wujud Perlindungan Anak Yang Berhadapan Dengan Hukum", Jurnal Penelitian Hukum DE JURE, Vol.16, No.4, December 2016, p.428

${ }^{8}$ Oscar Stefanus Setjo and Umar Ma'ruf, "Investigation of Children Which Conflicting With Law in Narcotics Criminal Acts In Law Area of the Semarang City Police Jurisdiction", Jurnal Daulat Hukum Volume 3 Issue 2, June 2020, p.287-288.

${ }^{9}$ Sri Endah Wahyuningsih, "Perlindungan Hukum terhadap Anak Sebagai Korban Tindak Pidana Kesusilaan Dalam Hukum Pidana Positif Saat Ini", Jurnal Pembaharuan Hukum Volume III No. 2 May - August 2016, p. 173.
} 
alternative treatment for children by keeping children away from the formal justice system as much as possible. Whereas children under any circumstances must continue to grow and develop as they should and children who are in conflict with the law must receive philosophical justice including shifting the retributive legal approach to restorative ones. ${ }^{10}$

According to the Director of Analysis of Legislations at Bappenas, Diani Sadia Wati, the reasons for the change of Act No. 3 of 1997 concerning Juvenile Court to Act No. 11 of 2012 concerning the Juvenile Criminal Justice System (UU SPPA) are due to several things as follows: First, the failure of the juvenile criminal justice system to produce justice; Second, the level of crime and child recidivism has not decreased; Third, the judicial process failed to treat children; fourth, the court makes more use of the crime of deprivation of liberty (imprisonment) than other forms of sanctions; and fifth, an overly legalistic approach. ${ }^{11}$

Retno Sudewi as The Head of the Central Java Women's Empowerment, Child Protection, Population Control, and Family Planning (DP3AP2KB) Office said that during 2020 to 2021 there were 634 criminal cases committed by children, where the crimes committed were in the form of theft, brawls, abuse, and cases of sexual crimes. .Retno Sudewi added that most of the children or adolescents in Central Java who were in conflict with the law were decided by the judge to enter the juvenile prison. In addition, the lengthy legal process against children in conflict with the law resulted in the child being depressed and could make the child's psychology more shaken. This will obviously have an impact on the development of the child's soul and also the child's future. ${ }^{12}$

Restorative justice present as another effort to enforce the law by not injuring children's rights, restorative justice is carried out by diversion. Restorative justice in handling children in conflict with the law can be pursued at the level of investigation, prosecution, examination through diversion efforts. The implementation of diversion in children's cases is carried out by means of a child case with the threat of criminal sanctions of up to 1 year must receive priority in the application of discretion so that the child's case does not need to go through a formal legal process. In the case of a child with the threat of a sanction exceeding 1 (one) year to a limit of under 7 (seven) years and not being a resident, then what is applied is diversion

\footnotetext{
10 Bambang Sukoco, Dosen Fakultas Hukum Universitas Muhammadiyah Surakarta, 2015, Pendekatan Restoratife Justice sebagai Upaya Penyelesaian Tindak Pidana Cyber dengan Pelaku Anak, paper prepared as an assignment for criminal law courses and the development of information technology, page 16

11 http://www.bappenas.go.id/berita-dansiaran-pers/indonesia-akan-berlaku-uuno-11tahun-2012-about-sistem-peradilanpidana-anak/, accessed on 29 October 2015.

12 Retno Sudewi, Personal Interview with the Head Office of Women's Empowerment, Child Protection, Population Control, and Family Planning (DP3AP2KB) Central Java, Interview conducted on 12 June 2021.
} 
with a restorative justice approach. ${ }^{13}$ Referring to the philosophical basis of the application of this diversion which aims to provide protection for children by keeping children away from imprisonment and confinement, of course it cannot be applied evenly. ${ }^{14}$ Children who are perpetrators of criminal acts whose threats are above 7 years in prison are of course processed by law without going through diversion efforts, this shows that legal protection for children who are in conflict with the law in the investigation process has not been able to be provided by the state. In its development, according to Retno Sudewi, children's cases have not entirely used diversion, punishment is still based on actions not in the interests of the child. 15

Then in reality there is an examination process, children who are in conflict with the law are forced to follow procedures commonly followed by adults. This situation allows the child to be under duress where he has to go through an examination process that has become a habit of police officers in conducting investigations and investigations in handling criminal cases. ${ }^{16}$ The various explanations that exist show that the law has contradicted its original purpose. Associated with legal purposes, Sri Endah stated that: ${ }^{17}$

If what national law aspires to is the Pancasila legal system, then it is appropriate to study and develop laws containing the values of Pancasila, meaning laws that are oriented to the value of the One Godhead, laws that are oriented to the values of Just and Civilized Humanity, laws based on on the value of Unity, and the law which is imbued with the value of Democracy Led by Wisdom of Wisdom in Deliberation/Representation and the value of Social Justice for All Indonesian People.

The concept of a state of law (nomocracy) has guaranteed the principle of equality of rights before the law (before the law), so the concept of development law that prioritizes openness (transparency) is commensurate with the offer of law formation as a consensus involving the public sphere prioritize deliberative democracy. ${ }^{18}$

\footnotetext{
${ }^{13}$ Ibnu Suka, Gunarto, and Umar Ma'ruf, “Peran Dan Tanggung Jawab Polri Sebagai Penegak Hukum Dalam Melaksanaan Restorative Justice Untuk Keadilan Dan Kemanfaatan Masyarakat", Jurnal Hukum Khaira Ummah Vol. 13. No. 1 March 2018, p. 115-116.

${ }^{14}$ M. Gargarin Friyandi and Aryani Witasari, "Restorative Justice In Application For Crime Investigation Abuse In Polsek Middle Semarang", Jurnal Daulat Hukum Volume 2 Issue 1, March 2019, p. 41-44.

${ }^{15}$ Sarwadi and Bambang Tri Bawono, "Restorative Justice Approach in Diversion System for Settlement of Criminal Cases for Children in Indonesia", Jurnal Daulat Hukum Volume 3 Issue 4, December 2020, p. 377-400.

${ }^{16}$ Arif Septria Hendra Saputra, Gunarto, and Lathifah Hanim, "Penerapan Restoratife Justice Sebagai Alternatif Penyelesaian Tindak Pidana Penganiayaan Di Satreskrim Polsek Lasem", Jurnal Daulat Hukum Vol. 1. No. 1 March 2018, p. 159.

${ }^{17}$ Sri Endah Wahyuningsih, Prinsip-Prinsip Individualisasi Pidana Dalam Hukum Islam Dan Pembaharuan Hukum Indonesia, UNDIP, Semarang 2013, p. 68.

${ }^{18}$ Sri Endah Wahyuningsih, "Kebijakan Penegakan Hukum Pidana Terhadap Penanggulangan Money Laundering Dalam Rangka Pembaharuan Hukum Pidana Di Indonesia", Jurnal Pembaharuan Hukum Volume III No. 2 May - August 2016, p. 47.
} 


\section{Closing}

The implementation of child protection in the investigation process in Central Java has not been able to run effectively, Most of the children or adolescents in Central Java who are in conflict with the law are decided by the judge to enter the juvenile prison. In addition, the lengthy legal process against children in conflict with the law results in the child being depressed and can make the child's psychology more shaken. It is necessary to make a supervision system in the legal process of children who are in conflict with the law so that children's rights and children's psychology are not injured.

\section{References}

\section{Journal}

[1] Arif Septria Hendra Saputra, Gunarto, dan Lathifah Hanim, "Penerapan Restoratife Justice Sebagai Alternatif Penyelesaian Tindak Pidana Penganiayaan Di Satreskrim Polsek Lasem”, Jurnal Daulat Hukum Vol. 1. No. 1 March 2018

[2] Hardianto Djanggih, "Konsepsi Perlindungan Hukum Bagi Anak sebagai Korban Kejahatan Siber Melalui Pendekatan Penal dan Non Penal", Jurnal Mimbar Hukum, Vol.30, No.2, June 2018

[3] Ibnu Suka, Gunarto, dan Umar Ma'ruf, “Peran Dan Tanggung Jawab Polri Sebagai Penegak Hukum Dalam Melaksanaan Restorative Justice Untuk Keadilan Dan Kemanfaatan Masyarakat", Jurnal Hukum Khaira Ummah Vol. 13. No. 1 March 2018

[4] Muhammad Azil Maskur, "Perlindungan Hukum Terhadap Anak Nakal (Juvenile Delinquency) Dalam Proses Acara Pidana Indonesia", Pandecta: Research Law Journal, Vol.7, No.2, 2012

[5] Nur Cahyanti, Budi Raharjo, dan Sri Endah Wahyuningsih, "Sanksi Terhadap Notaris Yang Melakukan Tindak Pidana Menurut Peraturan Perundang-Undangan Di Indonesia", Jurnal Akta, Vol 5 No 1 March 2018

[6] Nur Rochaeti, "Implementasi Keadilan Restoratif dan Pluralisme Hukum Dalam Sistem Peradilan Pidana Anak di Indonesia, Jurnal Masalah-Masalah Hukum, Vol. 44, No.2, April 2015

[7] Oscar Stefanus Setjo dan Umar Ma'ruf, "Investigation of Children Which Conflicting With Law in Narcotics Criminal Acts In Law Area of the Semarang City Police Jurisdiction", Jurnal Daulat Hukum Volume 3 Issue 2, June 2020

[8] Sarwadi dan Bambang Tri Bawono, "Restorative Justice Approach in Diversion System for Settlement of Criminal Cases for Children in Indonesia", Jurnal Daulat Hukum Volume 3 Issue 4, December 2020

[9] Sri Endah Wahyuningsih, "Perlindungan Hukum terhadap Anak Sebagai Korban Tindak Pidana Kesusilaan Dalam Hukum Pidana Positif Saat Ini", Jurnal Pembaharuan Hukum Volume III No. 2 May - August 2016

[10] Sri Endah Wahyuningsih, "Kebijakan Penegakan Hukum Pidana Terhadap Penanggulangan Money Laundering Dalam Rangka 
Pembaharuan Hukum Pidana Di Indonesia", Jurnal Pembaharuan Hukum Volume III No. 2 May - August 2016

[11] Ulang Mangun Sosiawan, "Perspektif Restorative Justice Sebagai Wujud Perlindungan Anak Yang Berhadapan Dengan Hukum”, Jurnal Penelitian Hukum DE JURE, Vol.16, No.4, December 2016

[12] Yul Ernis, "Diversi Dan Keadilan Restoratif Dalam Penyelesaian Perkara Tindak Pidana Anak Di Indonesia", Jurnal Ilmiah Kebijakan Hukum, Vol.10, No.2, July 2016

[13] Zendy Wulan Ayu Widhi Prameswari, "Ratifikasi Konvensi Tentang Hak-Hak Anak Dalam Sistem Peraturan Perundang-Undangan Di Indonesia", Jurnal Yuridika, Vol.32, No.1, January 2017

\section{Book}

[1] Gatot Supramono, 2007, Hukum Acara Pengadilan Anak, Djambatan, Jakarta

[2] M.Gargarin Friyandi dan Aryani Witasari, Restorative Justice In Application For Crime Investigation Abuse In Polsek Middle Semarang, Jurnal Daulat Hukum Volume 2 Issue 1, March 2019

[3] M Ghufran H. Kordi K, 2015, Durhaka Kepada Anak Refleksi Mengenai Hak \& Perlindungan Anak, Yogyakarta: Pustaka Baru Press

[4] Sri Endah Wahyuningsih, 2013, Prinsip-Prinsip Individualisasi Pidana Dalam Hukum Islam Dan Pembaharuan Hukum Indonesia, UNDIP, Semarang

[5] Sugiono, 2009, Metode Penelitian Kuantitatif, Kualitatif dan R\&D, Alfabeta, Bandung

\section{Interview}

[1] Retno Sudewi, Personal Interview with the Head of the Office of Women Empowerment, Child Protection, Population Control, and Family Planning (DP3AP2KB) Central Java, Interview conducted on 12 June 2021 